\title{
Laporan Kasus: Manajemen Perawatan Gigi pada Pasien dengan Periodontitis Kronis disertai Diabetes Mellitus
}

(Case Report: Dental Management of patient with chronic periodontitis and diabetes mellitus)

Agus Surachman 1 , Marsaa Paramita ${ }^{2 *}$, Aris Aji Kurniawan ${ }^{3}$

1 Bagian Bedah Mulut, RSGMP Universitas Jenderal Soedirman, Purwokerto, Indonesia

$2^{*}$ Program Studi Profesi Dokter Gigi, Universitas Jenderal Soedirman, Purwokerto, Indonesia

3 Bagian IImu Penyakit Mulut Jurusan Kedokteran Gigi Fakultas Kedokteran Universitas Jenderal Soedirman, Punwokerto Indonesia

\section{Abstrak}

Diabetes mellitus merupakan penyakit metabolik yang menunjukkan tubuh tidak bisa mengatur glukosa dalam darah karena kekurangan insulin pada diabetes tipe I dan defisiensi insulin pada diabetes tipe II. Kondisi diabetes dapat memperparah jaringan periodontalTujuan laporan kasus adalah menjelaskan tentang karakteristik, manifestasi oral dan manajemen gigi pasien dengan diabetes. Seorang wanita 53 tahun mengeluh ingin dibuatkan gigi palsu. Pemeriksaan intraoral menunjukkan terdapat kehilangan gigi 35, 36, 37, 46, 47 serta radiks gigi 23 , $24,27$. 38, 48. Pasien punya riwayat penyakit diabetes dengan terapi oral saat ini Metformin 500 mg dan telah mengkonsumsinya sejak 2016. Rencana perawatan yaitu edukasi, control plak dengan scaling supragingiva kemudian ekstraksi radiks dan pembuatan gigi tiruan sebagian lepasan. Berdasarkan hasil uji lab menunjukkan kadar glukosa dalam darah pada bulan oktober $177 \mathrm{mg} / \mathrm{dl}$. Pasien diinstruksikan mejaga oral hygiene dibantu dengan peresepan obat kumur dan melanjutkan pengobatan untuk penyakit diabetes.Perawatan gigi pada pasien dengan penyakit diabetes harus mempertimbangkan berbagai hal seperti kondisi pasien, pengurangan stres, modifikasi diet makanan, obat profilaksis, dan pemantauan rutin kadar glukosa darah

Kata kunci: Diabetes melitus, manifestasi oral dengan diabetes melitus, periodontitis

\section{Abstract}

Diabetes mellitus is a metabolic disease in which blood sugar levels are abnormally because the body does not produce enough insulin (type 1) and insulin deficiency (type II). The condition of diabetes can worsen the periodontal tissue. Purpose of this case report is to explain the characteristics, oral manifestations and dental management of patients with diabetes. A 53-year-old request to made aartificial denture. Intraoral examination presented loss of teeth $35,36,37,46,47$ and dental roots 23,24, 27, 38, 48. Patients have a history of diabetes with Metformin $500 \mathrm{mg}$ oral therapy and have consumed it since 2016. The treatment plan is education, plaque control with supragingival scaling then extraction of the roots dental and making of removable partial dentures. Based on the results of lab tests showed blood glucose levels in October $177 \mathrm{mg} / \mathrm{dl}$. Patients were instructed to maintain oral hygiene with mouthwash prescriptions and to continue diabetes treatment. Dental care in patients with diabetes must consider various things such as the patient's condition, stress reduction, dietary modifications, prophylactic medications, and routine monitoring of blood glucose levels

Keywords: Diabetes mellitus, oral manifestations with diabetes mellitus, periodontitis

Korespondensi (Correspondence) : Marsaa Paramita, Kedokteran Gigi Universitas Jenderal Soedirman, Jl Dr Soeparno, Rumah Sakit Gigi dan Mulut Unsoed, Banyumas, Jawa Tengah 53122. Email: marsaaparamita@ymail.com

Diabetes mellitus adalah kelainan metabolisme umum yang menunjukkan tubuh tidak bisa mengatur kadar glukosa dalam darah karena kekurangan insulin absolut (penurunan produksi insulin pada diabetes tipe I) atau defisiensi insulin relatif (peningkatan resistensi terhadap insulin oleh jaringan pada diabetes tipe 2)'. Studi epidemiologi menunjukkan bahwa diabetes mellitus meningkatkan faktor resiko dan keparahan penyakit periodontal ${ }^{2,3}$.

Penyakit periodontal merupakan salah satu penyakit rongga mulut yang disebabkan oleh adanya plak. Penyakit periodontal dikenal sebagai infeksi bakterial yang dapat menyerang jaringan periodontal dan dapat menimbulkan berbagai kondisi, terutama gingivitis dan periodontitis. Gingivitis ialah inflamasi gingiva tanpa terjadi kehilangan perlekatan klinis, sedangkan periodontitis berawal dari inflamasi gingiva yang kemudian mengalami kehilangan perlekatan klinis dari jaringan periodontal dan jika tidak dilakukan perawatan akan menyebabkan kehilangan gigi4. Diabetes melitus bukan merupakan penyebab timbulnya penyakit periodontal, tetapi pada penderita diabetes melitus dengan kadar gula darah yang relatif tinggi (>200mg/dl) akan cenderung meningkatkan insiden dan keparahan periodontitis. Perawatan rongga mulut pada pasien dengan diabetes juga berbeda dengan pasien tanpa diabetes. Oleh karena itu dibutuhkan beberapa tahap pemantauan sebelum dilakukannya perawatan maupun selama perawatan. Tujuan artikel ini adalah untuk menggambarkan hubungan antara penyakit sistemik diabetes mellitus dengan penyakit periodontal terutama periodontitis dan beberapa hal yang harus dilakukan 
dalam perawatan rongga mulut pasien dengan diabetes mellitus.

\section{LAPORAN KASUS}

Seorang wanita usia 53 tahun datang ke Rumah Sakit Gigi dan Mulut (RSGM) Universitas Jenderal Soedirman Purwokerto dengan keluhan ingin dibuatkan gigi palsu rahang atas dan rahang bawah. Pasien mengaku memiliki riwayat penyakit hipertensi akan tetapi sudah terkontrol dan riwayat penyakit diabetes mellitus. Pasien mengkonsumsi obat rutin per oral yaitu Metformin. Pemeriksaan umum menunjukkan tekanan darah 130/80 $\mathrm{mmHg}$, berat badan $45 \mathrm{~kg}$ dan tinggi badan $142 \mathrm{~cm}$. pasien mengikuti kegiatan PROLANIS (Program pengelolaan penyakit kronis) di Puskesmas. Hasil pemeriksaan gula darah beberapa bulan lalu yang dilakukan saat kegiatan PROLANIS dan di RSGM (table 1 dan 2).

Pasien tidak memiliki riwayat alergi obat maupun alergi makanan, namun memiliki riwayat penyakit sistemik asma, hipertensi dan diabetes. Untuk penyakit asma, pasien tidak mengkonsumsi obat oral rutin namun menggunakan obat hirup (Inheler) kalau terjadi sesak nafas. Penyakit hipertensi pada pasien ini pernah tinggi hingga mencapai 190/80 mmHg akan tetapi kondisi sekarang sudah normal yaitu $130 / 80 \mathrm{mmHg}$. Pada pemeriksaan gula darah sewaktu terlihat hasil sebesar $177 \mathrm{mg} / \mathrm{dl}$ dari angka normal $<140 \mathrm{mg} / \mathrm{dl}$. Pasien telah mengikuti program PROLANIS Untuk mengobati penyakit diabetes yang juga diberikan terapi obat minum oral Metformin 500mg sejak tahun 2016. Pemeriksaan ekstraoral secara inspeksi menunjukkan tidak adanya kelainan. Pemeriksaan intraoral terdapat resesi gingiva pada area gigi anterior rahang bawah dan mobilitas gigi derajat 2 pada gigi 14,45 . Terdapat kalkulus supragingiva pada area lingual anterior rahang bawah dengan oral hygiene pasien yang cukup baik. Pemeriksaan klinis menunjukkan terdapat kehilangan gigi $35,36,37,46,47$ serta radiks gigi 23, 24, 27, 38, 48 (gambar 1). Pasien dilakukan pemeriksaan penunjang berupa radiografi ekstra oral (panoramik) untuk melihat kondisi tulang alveolar secara keseluruhan (gambar 2).

Tabel 1. Pemeriksaan gula darah rutin pasien di PROLANIS

\begin{tabular}{cc}
\hline Pemeriksaan gula darah sewaktu 2019 & Hasil \\
\hline Juni & $425 \mathrm{mg} / \mathrm{dl}$ \\
Juli & $320 \mathrm{mg} / \mathrm{dl}$ \\
Agustus & $400 \mathrm{mg} / \mathrm{dl}$ \\
September & $295 \mathrm{mg} / \mathrm{dl}$ \\
\hline
\end{tabular}

Tabel 2. Pemeriksaan gula darah pada kunjungan pertama di RSGM

\begin{tabular}{cc}
\hline Pemeriksaan gula darah 2019 & Hasil \\
\hline Gula darah sewaktu & $177 \mathrm{mg} / \mathrm{dl}($ normal $<140 \mathrm{mg} / \mathrm{dl})$ \\
\hline
\end{tabular}
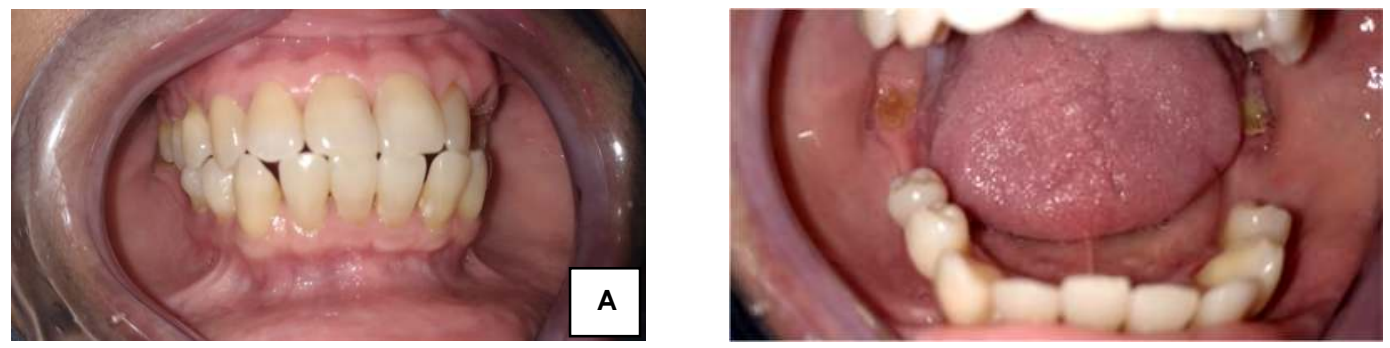

Gambar 1. Kondisi klinis rongga mulut pasien bagian anterior RA dan RB (A); Kondisi klinis rongga mulut pasien bagian posterior RB (B)

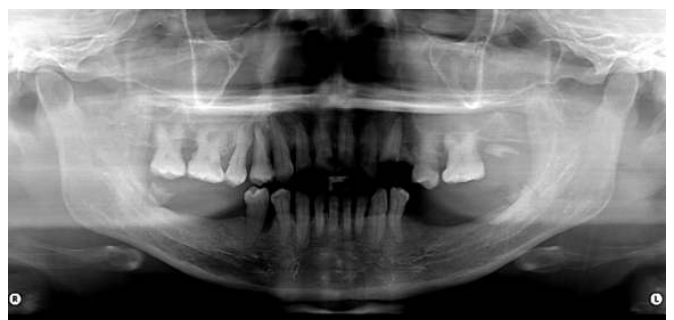

Gambar 2. Pemeriksaan penunjang radiografi panoramik 
Pada gambaran radiografi terdapat gambaran radiolusen pada ketinggian puncak tulang alveolar. Terlihat adanya penurunan tulang secara horizontal pada rahang bawah di area gigi 44, 43, 42, 41, 31, $32,33,34$ kemudian pada rahang atas di area gigi 13, 12, 11, 21, 22. Terlihat adanya penurunan tulang secara vertikal pada area gigi 45. Diagnosis pada kasus ini adalah periodontitis kronis. Rencana perawatan yang akan dilakukan yaitu ekstraksi seluruh sisa akar gigi rahang atas dan bawah dilanjutkan pembuatan gigi tiruan penuh. Pada kunjungan pertama pasien diberikan Dental Health Education (DHE) diresepkan obat kumur povidone iodine 1\% untuk membantu menjaga kebersihan rongga mulut (kontrol plak) dan edukasi tahapan perawatan. Setelah itu pasien dilakukan perawatan periodontal awal yaitu scaling supragingiva. Kemudian setelah mengkontrol plaknya, pasien dilakukan rujukan kepada dokter spesialis penyakit dalam untuk konsultasi terkait kondisi sistemik pasien terhadap rencana perawatan berikutnya yang akan dilakukan. 2 hari sebelum tindakan pencabutan, pasien akan diresepkan obat antibiotik per oral untuk mencegah komplikasi saat tindakan pencabutan berlangsungdan dilakukan pengecekkan gula darah sewaktu kembali sesaat sebelum tindakan untuk memantau angka gula darah dalam tubuh. Setelah dilakukan pencabutan semua sisa akar gigi, pasien dievaluasi untuk dibuatkan gigi tiruan sebagian lepasan.

\section{PEMBAHASAN}

Diabetes mellitus (DM) adalah penyakit metabolik yang ditandai oleh peningkatan kadar glukosa darah (hiperglikemi). Diabetes merupakan suatu sindrom defisiensi sekresi insulin atau pengurangan efektivitas kerja insulin atau keduanya. Insufisiensi insulin dapat disebabkan oleh gangguan produksi insulin oleh sel-sel Langerhans kelenjar pankreas atau disebabkan oleh kurangnya respontif selsel tubuh terhadap insulin. Diabetes diklasifikasikan menjadi 2 tipe yaitu tipe I dan tipe II. Tipe I disebut juga sebagai diabetes mellitus bergantung insulin yang merupakan jenis diabetes yang paling berat dan paling banyak dialami oleh usia muda serta muncul jika sirkulasi insulin tidak tampak secara nyata. Diabetes tipe 2 terjadi oleh karena kerusakan molekul insulin atau gangguan reseptor insulin yang mengakibatkan kegagalan fungsi insulin untuk mengubah glukosa menjadi energi. Pada dasarnya pada diabetes tipe 2 jumlah insulin dalam tubuh adalah normal bahkan jumlahnya bisa meningkat, namun karena jumlah reseptor insulin pada permukaan sel berkurang menyebabkan glukosa yang masuk kedalam sel lebih sedikit. Hal tersebut akan terjadi kekurangan jumlah glukosa dan kadar glukosa menjadi tinggi didalam pembuluh darah. Diabetes tipe ini sering terjadi pada dewasa yang berumur lebih dari
30 tahun dan menjadi umum dengan peningkatan usia ${ }^{5,6,7,8}$.

Pengobatan diabetes melitus difokuskan pada penatalaksanaan kadar glukosa darah, pemberian insulin atau agen hipoglikemik oral, penatalaksanaan diet, kontrol terhadap berat badan dan pengaturan aktivitas ${ }^{7}$. Hiperglikemi yang terjadi dari waktu ke waktu dapat menyebabkan kerusakan berbagai sistem tubuh terutama syaraf dan pembuluh darah.beberapa konsekuensi dari diabetes yang sering terjadi berupa: meningkatnya resiko penyakit jantung dan stroke, neuropati di kaki yang dapat meningkatkan kejadian ulkus kaki, retinopati diabetikum yang merupakan salah satu penyebab utama kebutaan dan gagal ginjal9. Kriteria diagnostik diabetes mellitus menurut American Diabetes Association 2010 adalah sebagai berikut; 1. Gejala klasik DM dengan glukosa darah sewaktu > 200mg/dl. Glukosa darah sewaktu merupakan hasil pemeriksaan sesaat pada suatu hari tanpa memerhatikan waktu makan terakhir. Gejala klasik adalah poliuria, polidipsi dan berat badan turun tanpa sebab. 2. Kadar glukosa darah puasa $>126 \mathrm{mg} / \mathrm{dl}$. Puasa adalah pasien tidak mendapatkan kalori sedikitnya 8 jam. 3. Kadar glukosa darah 2 jam PP> $200 \mathrm{mg} / \mathrm{dl}$. Tes toleransi glukosa oral dilakukan dengan standar WHO yang menggunakan beban glukosa yang setara dengan $75 \mathrm{gr}$ glukosa anhidrus yang dilarutkan ke dalam airl. Kadar gula darah yang tidak terkontrol akan menyebabkan komplikasi diantaranya adalah komplikasi kesehatan mulutio.

Diabetes dapat dihubungkan dengan berbagai macam komplikasi kesehatan mulut. Pasien dengan diabetes yang tidak terkontrol memiliki peningkatan resiko infeksi mulut, penurunan aliran saliva dan gangguan penyembuhan luka'l. Selain itu pada pasien diabetes juga mengalami disfungsi sekresi kelenjar saliva yang disebut Xerostomia dimana kualitas dan kuantitas produksi saliva dirongga mulut menurun sehingga kondisi bakteri dan jamur meningkat. Respon terhadap plak bakteri juga berbeda karena meningkatnya kadar sitokin dalam jaringan gingiva dan juga peningkatan konsentrasi glukosa dalam cairan crevicular mampu mengubah komposisi bakteri dan mikrobiota oral' $^{2}$. Berdasarkan penelitian yang dilakukan oleh Aren dkk. menunjukkan kadar glukosa juga tinggi kandungannya dalam saliva. Peningkatan glukosa ini juga berakibat pada kandungan pada lapisan biofilm dan plak pada permukaan gigi yang berfungsi sebagai tempat perlekatan bakteri. Hal ini dapat menyebabkan terjadinya karies dan perkembangan penyakit periodontal ${ }^{13}$. Penyakit periodontal termaksud gingivitis dimana peradangan terbatas pada gingiva dan periodontitis dimana peradangan meluas dan menyebabkan kerusakan jaringan serta resorpsi tulang alveolar. Kerusakan jaringan pada periodontitis menyebabkan kerusakan serat kolagen ligamen periodontal yang 
menghasilkan pembentukkan periodontal pocket antara gingiva dan gigi. Periodontal pocket tidak dapat diukur melalui visual sederhana, harus diukur menggunakan periodontal probe. Tahap awal periodontitis biasanya tanpa gejala, tanpa rasa sakit dan banyak masyarakat tidak sadar sampai kondisinya cukup berkembang sehingga menyebabkan mobilitas gigil4.

Periodontitis adalah penyakit peradangan kronis yang kompleks dimana inflamasi pada jaringan periodontal dirangsang oleh kehadiranjangka panjang dari biofilm yang berada pada subgingiva (plak gigi). Keberadaan bakteri subgingival seperti a. Actinomycetemcomitans, Porphyromonas gingivalis memicu terjadinya penyakit periodontal serta berperan penting dalam pembentukan poket dan destruksi tulang. Hal ini disebabkan karena adanya produk yang dihasilkan bakteri seperti enzim proteolitik, leukotoksin, endotoksin, lipopolisakarida, asam lipoteikhoik, peptidoglikan yang dapat merangsang terjadi resorpsi tulang. Produk ini akan meningkatkan deferensiasi sel progenitor tulang menjadi osteoklas dan merangsang sel gingiva untuk mengeluarkan suatu mediator inflamasi seperti IL-6 dan TNF-a yang dapat memicu terjadinya kerusakan tulang ${ }^{15}$. Respon inflamasi ditandai oleh sekresi tidak teratur dari mediator yang diturunkan dari inang inflamasi dan kerusakan jaringan diantaranya adalah IL-1 $\beta$, IL-6 prostaglandin E2 (PGE2), TNF-a, receptor activator of nuclear factor $k B$ ligand (RANKL), matrix metalloproteinase (MMPs), sitokin pengatur sel T (IL-12, IL-18) dan kemokin.

Mediator inflamasi ini dapat menyebabkan peningkatan resistensi insulin dan karenanya membuat pasien lebih sulit untuk mempertahankan kontrol glikemik 5,11.Kedua diabetes mellitus tipe 1 dan tipe 2 dikaitkan dengan peningkatan tanda peradangan sistemik. Pada pasien diabetes, menunjukkan adanya cacat dalam aktivitas leukosit polimorfonuklear (PMN) seperti kecacatan dalam kemotaksis, fagositosis dan apoptosis sehingga menyebabkan peningkatan retensi PMN pada jaringan periodontal yang mengarah ke penghancuran jaringan periodontal dengan melepaskan MMPs dan reactive oxygen species (ROS) ${ }^{16,17}$. Pada sebuah penelitian memberi dukungan gagasan bahwa perbaikan dalam kontrol penyakit metabolik dapat diantisipasi setelah perawatan periodontitis yang efektif. Mekanisme terjadinya hal ini belum jelas tetapi mungkin berhubungan dengan berkurangnya peradangan sistemik contohnya penurunan kadar serum mediator seperti TNF-a dan IL-6 setelah perawatan dan perubahan peradangan periodontal18. Akan tetapi, apabila gigi tidak dapat dipertahankan maka akan dlakukan proses pencabutan. Pencabutan gigi pada pasien diabetes dibutuhkan perhatian khusus karena glukosa yang tinggi dalam pembuluh darah akan menyebabkan komplikasi saat proses pendarahan pada pencabutan. Oleh karena itu, dibutuhkan perhatian khusus terkait perawatan pencabutan pada pasien dengan diabetes.

Pasien dengan diabetes yang tidak terkontrol berisiko mengalami komplikasi oral karena kerentanan mereka terhadap infeksi. Antisipasi operasi dentoalveolar menggunakan antibiotik dapat membantu mencegah gangguan dan menunda penyembuhan luka. Infeksi orofacial membutuhkan pemantauan yang ketat. Sebaiknya kultur harus dilakukan untuk beberapa kemungkinan infeksi akut. Tindakan sebaiknya dilakukan pada pagi hari dan lebih disukai 2 jam setelah sarapan dan medikasi pagi untuk menghindari waktu aksi puncak bagi pasien dengan suntikan insulin karena kadar kortisol endogen umumnya lebih tinggi pada saat ini. Disarankan untuk menghindari perjanjian perawatan apabila pasien: belum memiliki obat atau makan, sedang mengalami flu atau kelelahan, sudah lama belum konsultasi dengan dokter pribadinya, memiliki kadar gula $<70 \mathrm{mg} / \mathrm{dl}$ atau $>150$ $\mathrm{mg} / \mathrm{dl}$, dan mengalami darurat akhir-akhir ini'19. Pada suatu penelitian mengungkapkan beberapa kondisi yang terjadi setelah pencabutan pada pasien diabetes. Pasien dengan kadar gula dara 170-220 mg/dl memiliki komplikasi berupa nyeri dan pembengkakan di sekitar area yang di ekstraksi. Untuk kadar gula darah 220-250 $\mathrm{mg} / \mathrm{dl}$ merasakan sensasi terbakar di sekitar alveolus dan hambatan utama dalam penyembuhan luka dialam pada pasien dengan kadar gula darah sekitar $250 \mathrm{mg} / \mathrm{dl}$ yang memiliki kecenderungan terhadap dry socket20.

Diabetes mellitus bukan penyakit yang dapat disembuhkan. Pasien diabetes yang membutuhkan perawatan rongga mulut dibutuhkan pemantauan ekstra agar tidak terjadi komplikasi yang tidak terkontrol. Beberapa yang perlu diperhatikan adalah ${ }^{21}$ :

1. Menjaga kadar glukosa sedekat mungkin dengan kadar gula darah normal

2. Berusah mempertahankan berat badan yang ideal

3. Memilih perawatan yang sederhana dan sebaik-sebaiknya

4. Melakukan diet makanan dan melakukan aktivitas fisik yang baik sebelum tindakan perawatan

5. Memantau penggunaan insulin maupun obat oral yang dikonsumsi secara teratur

6. Diberikan profilaksis antibiotik sebelum dilakukan tindakan invasif untuk mencegah infeksi luas

7. Memperbaiki pola hidup dan menghindari stres 22

8. Hindari perawatan gigi bila gula darah tinggi dan tidak terkontrol22

9. Menggunakan pembersih mulut antibakteri untuk mengurangi bakteri 
penyebab kerusakan gigi dan jaringan lunak di sekitar gigi22

Pemantauan kondisi sistemik pasien dengan diabetes mellitus dibutuhkan untuk mendukung keberhasilan perawatan gigi. Dilakukan beberapa pencegahan sebelum dilakukannya perawatan diharapkan mampu mengurangi tingkat kejadian komplikasi yang tidak diinginkan. Pemantauan secara rutin kadar gula darah penting terutama sesaat sebelum dilakukannya tindakan invasif. Mengotrol kebersihan rongga mulut pasien dibutuhkan untuk menekan kejadian infeksi lebih lanjut karena pasien dengan diabetes rentan terhadap pertumbuhan bakteri maupun jamur.

\section{KESIMPULAN}

Diabetes mellitus (DM) adalah penyakit metabolik yang ditandai oleh peningkatan kadar glukosa darah (hiperglikemi). Diabetes dapat dihubungkan dengan berbagai macam komplikasi kesehatan mulut. Pasien dengan diabetes yang tidak terkontrol memiliki peningkatan resiko infeksi mulut, penurunan aliran saliva, gangguan penyembuhan luka dan penyakit periodontal diantaranya gingivitis dan periodontitis. Pada perawatan rongga mulut dapat mempertimbangkan beberapa hal diantara, pemantauan kadar gula darah rutin, mengontrol plak, modifikasi diet makanan, menghindari stres, penentuan jadwal kunjungan perawatan dan menyediakan obat-obatan gawat darurat

\section{DAFTAR PUSTAKA}

1. American Diabetes Association. 2014. Diabetes care. Journal and Applied Research an Education. 42(1): 51-193

2. Newman, MG. Takei, HH. Carranza, FA. 2002. Carranza's Clinical Periodontology. 9th ed. Philadelphia: W.B. Saunders Co.

3. Taylor, GW. 2003. The Effect of Periodontal Treatment on diabetes. JADA. 134

4. Savira, NV. Hendiani, I. Komara, I. 2017. Kondisi Periodontal Diabetes Mellitus Tipe I. J Ked Gigi Unpad. 29(2): 151-158

5. Preshaw, PM. Taylor, JJ. 2011. How has Research into Cytokine Interaction and Their Role in Driving Immune Responses Impacted our Understanding of Periodontitis. Journal Clinical Periodontolgi. 38(1 1 1): 60-84

6. Suyuno, S. 2005. Patofisiologi Diabetes Mellitus Terkini dalam Penatalaksanaan Diabetes Melitus Terpadu. Balai Penerbitan FKUI. Jakarta
7. Marrelli, TM. 2008. Buku SakuDokumentasi Keperawatan Ed. 3. Jakarta. Penerbitan Buku Kedokteran EGC

8. Kinane, O. F., dan Marshall, G.J., Periodontal Manifestation of Systemic Disease, Australian Dental journal, 2001; 46 (1):2-12

9. Kementerian Kesehatan RI. 2014. Situasi dan Analisis Diabetes. Jakarta. Pusat Data dan Informasi Kementerian Kesehatan RI

10. Keeling, HM. Wright, TL. 2015. Periodontal Disease and Diabetes Mellitus: Case Report. Clinical Case Report. 3(2): 61-68

11. Casanova, L. Hughes, FJ. Preshaw, PM. 2014. Diabetes and Periodontal Disease: A Two-way Relationship. British Dental Journal. 7(8): 433-437

12. Wang, TF. Jen, IA. Chou, C. Lei, YP. 2014. Effects of Periodontal Therapy on Metabolic Control in Patient with Type 2 Diabetes and Periodontal Disease. A meta-analysis Medicine. 93(28): 292

13. Aren, G. Sepet, E. Ozdemir, D. Dinccag, N. Guvener, B. Firatli, E. 2003. Periodontal Health, Saliva Status and Metabolic Control in Children with Type 1 Diabetes Mellitus. Journal Peridontal. 74(12): 17891795

14. Alfonso, L. Jepsen, S. Herrera, D. Konstantinidis, A. Makrilakis, R. Taylor. 2011. Periodontitis and Diabetes: A TwoWay Relationship. Diabetologia. 5(5): 2131

15. Caranza, F.A., Newman M.G., 2006, Clinical Perodontology. 10th edition, Philadelphia, Toronto, W.B. Sounders Co, 452-466, 506-521, 561-580

16. Graves, DT. Liu, R. Alikhani, M. Al-Mashat, H. Trackman, PC. 2006. DiabetesEnhanced Inflammation and Apoptosis Impact on Periodontal Pathology. J Dent Res. 85:15-21

17. Naguib, G. Al-Mashat, H. Desta, T. Graves, DT. 2004. Diabetes Prolongs the Inflammatory Respone to a Bacterial Stimulus through Cytokine Dysregulation. J Invest Dermatol. 123: 87-92

18. Stratton, IM. Adler, AL. Neil, HA. E† al. 2000. Association of Glycaemia with Macrovascular and Microvascular complication of Type 2 Diabetes: Prospective Observational Study. BMJ. 321: $405-412$ 
19. Singh, G. 2014. Dental Management of Diabetic Patient: A Clinical Review. Oral Medicine. 5(1): 26-30

20. Gupta, B. 2017. Assessment of Post Operative Wound Healing in Diabetic Patients After Extraction. International Journal of Advances in Scientific Research. 3(7): 77-81
21. Pandey, R. 2018. Dental Management of Diabetes Mellitus: Review of Literature. Journal of Research and Advancement in Dentistry. 7(3): 73-77

22. Respati, Titi N. Iwanda. 2006. Hubungan diabetes mellitus dengan karies gigi. Jurnal UNDIP.1 (2):

$5-10$ 